CORRECTION

\title{
Correction to: Network structure of resource use and niche overlap within the endophytic microbiome
}

Matthew Michalska-Smith, Zewei Song, Seth A. Spawn-Lee (D), Zoe A. Hansen (D, Mitch Johnson, Georgiana May, Elizabeth T. Borer, Eric W. Seabloom and Linda L. Kinkel (iD

(c) The Author(s) 2021

The ISME Journal (2022) 16:613; https://doi.org/10.1038/s41396-021-01160-0

Correction to: The ISME Journal https://doi.org/10.1038/s41396021-01080-z, published online 19 August 2021

In this article were the solid coloured boxes that should be present in the table legends for 1, 3 and 4 have printed as hollow boxes. For table 5, there should be symbols in the legend as per the table but these have been replaced with hollow boxes.

The original article has been corrected.

\begin{abstract}
(c) (i) Open Access This article is licensed under a Creative Commons Attribution 4.0 International License, which permits use, sharing adaptation, distribution and reproduction in any medium or format, as long as you give appropriate credit to the original author(s) and the source, provide a link to the Creative Commons license, and indicate if changes were made. The images or other third party material in this article are included in the article's Creative Commons license, unless indicated otherwise in a credit line to the material. If material is not included in the article's Creative Commons license and your intended use is not permitted by statutory regulation or exceeds the permitted use, you will need to obtain permission directly from the copyright holder. To view a copy of this license, visit http://creativecommons. org/licenses/by/4.0/.
\end{abstract}

(c) The Author(s) 2021 